\title{
INVESTIGATING THE IMPACT OF PERFORMANCE APPRAISAL JUSTICE ON JOB PERFORMANCE AND OCB OF EMPLOYEES: PATH THROUGH WORK ENGAGEMENT
}

\author{
Riffut Jabeen $^{1}$, Rabia Mushtaq ${ }^{2}$, Abida Ellahi ${ }^{3 *}$, Samina Begum ${ }^{4}$
}

${ }^{1}$ Lecturer, Department of Management Sciences, Ghazi University, Pakistan; ${ }^{2}$ Assistant Professor, Department of Management Sciences, Quaid e Azam University, Islamabad, Pakistan; ${ }^{3 * 4}$ Assistant Professor, Department of Management Sciences, Abbottabad University of Science \& Technology, Abbottabad, Pakistan.

Email: ${ }^{1 *}$ riffutjabeen@gmail.com, ${ }^{2}$ rabiakhanbuzdar@yahoo.com, ${ }^{3 *}$ abia.ell@gmail.com, ${ }^{4}$ samina.begum1982@gmail.com Article History: Received on $9^{\text {th }}$ April 2021, Revised on $5^{\text {th }}$ May 2021, Published on $11^{\text {th }}$ May 2021

Abstract

Purpose of the study: The study intends to find the interaction of Performance Appraisal Justice (PAJ) and work engagement (WE) to predict employee job performance (JP) and organizational citizenship behaviour (OCB) under the umbrella of fairness heuristic theory (JHT) and social exchange theory (SET).

Methodology: Hypotheses testing was done using linear regression data on the data set of 325 respondents. The results are significant and indicated that Justice in the performance appraisal system is positively related to employee outcomes (OCB and job performance) with mediating effect of work engagement.

Main Findings: Interaction between exogenous, endogenous, and intervening variables suggests that there is a positive relationship between PAJ and WE and WE mediate the relationship between PAJ and OCB and PAJ JP. In the organizational setting of Pakistan, this study addresses PAJ and its important outcomes which are beneficial for the organization's effective outcomes.

Applications of this study: This study throws light on the management, organizational, and administrative sciences literature, especially the human resource, organizations, and industrial behavior perspective. Administrators and human resource managers can apply the findings of this study. The study can be applied to both the public and private sectors.

Originality/Novelty: Pakistani organizations have high collectivism, uncertainty avoidance and power distance, centralization, bureaucracy, and authority in organizations. Therefore, this study has proved some prominent outcomes as compared to countries with a more constant climate. The study sheds light on very important aspects of workplace behavior such as justice, work engagement, $\mathrm{OCB}$, and performance with a particular focus on developing countries.

Keywords: Justice, Performance Appraisal Justice, OCB, Job Performance, Work Engagement.

\section{INTRODUCTION}

In this hyper turbulent and competitive environment, the sustainability of any organization largely rests on the positive behaviors and perceptions of employees towards the organizations while retention of key employees largely depends on the satisfaction of employees with the organization. Perceptions of employees towards an organization can steer the organization towards the destiny of success. Employees become more satisfied and engaged with an organization when they perceive that they are rewarded fairly for their work (Fatt, Khin \& Heng, 2010; Sherf, Venkataramani \& Gajendran, 2019). For understanding employee's perceptions and reactions towards the performance management system of the organization, organizational justice plays a key role (Palaiogos, Papazekos \& Panayotopoulou, 2011). Organizational Justice (OJ) is the combination of procedural, interactional, and distributive justice (Rupp et al., 2017). It refers to the overall and general perception of employees about the fairness of the human resource system of their organization (Imamoglu et al, 2019). In human resource management, the Performance Appraisal System (PAS) plays an integral part and comes under the wider concept of organizational justice. This is an ongoing process of communication between employees and the organization. Performance evaluation system provides useful feedback to employees to improve their performance in the future ( $\underline{\mathrm{Chen}, \mathrm{Li}}$ \& Lu, 2018; Murphy, 2020).

To make any system effective, all members who are involved in this system must observe it as a fair system, and fairness of system depends on when an employee receives a fair yield of his/her contribution and compares his/her input and output ratio based on equity (Wang \& Nayir, 2010). The quality of performance appraisal systems based on trust and fairness plays an important role in enhancing business unit performance (Baird, Tung \& Su, 2020). However, little knowledge has been gained to study the performance appraisal satisfaction model (Khan et al, 2020).

Pakistan has a collectivistic society having a robust influence of religion on all aspects of life, low-income economy, high level of unemployment and poverty rates (Abbas \& Raja, 2014), a surge of violence and terrorism, challenging and stressful 
work environment (Khan et al., 2019; Naseer et al., 2016; Kausar \& Anwar, 2010), with high collectivism, uncertainty avoidance and power distance (Adair \& Xiong, 2018; Gul et al., 2018).

\section{Need and objectives}

Therefore, there is a need to study such variables and phenomena that could affect the productive behaviors of employees. The main objective of this study is to examine the influence of performance appraisal justice on organizational citizenship behavior and job performance with a mediating role of work engagement. Hence, this study may produce more prominent outcomes as compared to countries with a more constant climate. After the introduction, literature review, methodology, results, and conclusion have been discussed.

\section{LITERATURE REVIEW}

\section{Supporting Theory}

For understanding an individual's behaviors at the workplace, social exchange is an important theoretical framework (Blau, 1964). We draw on social exchange theory which postulates that social exchange encompasses give and take processes between two parties involved in mutual responsibilities. According to the given empirical shreds of evidence, researchers believe that OCB and job performance are the most significant obligations of employees having an ultimate influence on organizational effectiveness (Thomas, Ambrosini \& Hughes, 2019). Work engagement is related to organizational goals accomplishments and performance (Schneider et al., 2018).

Due to OCB's discretionary and extra-role behavior, personnel became ready to perform beyond their instant task performance for their organization (Zhou et al., 2020). Podsakoff, Whiting, Podsakoff, and Blume (2009), establish a positive association between OCBs of employees and organizational performance. The study grounded on the SET established a mechanism that employee perception about fairness in PAS impacts the three critical outcomes, work engagement, job performance, and OCB in an exchange relationship.

In addition, the fairness heuristic theory also sheds light on the role of justice in the performance appraisal system in this proposed model of the study. It described that employees' behavior is dependent on fair treatment in the organization. After perceiving the level of fair treatment and judgments, employees decide either to think and behave prosaically or to safeguard their self-interests (Shanock et al., 2019; Shin et al., 2015). Based on this theory, the study hypothesized that justice and fairness in the appraisal system lead employees to positive organizational behaviors (WE, OCB, job performance). Employees identify themselves with a group having pro-social behaviors through justice in the system (Van et al., 2018). Employees internalize the positive behaviors that lead to improved organizational outcomes. The study has empirically validated the theory in the Pakistani cultural context.

\section{Organizational Justice and Work Engagement}

As a multi-dimensional construct, justice evolved as the extent to which employees get treated and paid by management on a fair basis. Justice is divided into procedural, distributive, interpersonal, and informational justices (Colquitt et al., 2005). Performance Appraisal Justice is based on social exchange theory (SET) that postulates social exchanges as a two-way giveand-take process (Blau, 1964). Grounded upon SET, the study proposes that employees offer their intellect, knowledge, talents, and efforts to their organizations and in return, they get rewards, benefits, wages, or salaries (Cropanzano et al., 2017). According to Flint and Haley (2013), perceptions of employees about distributive justice affect a numeral outcome in organizations such as OCB, commitment, performance, job satisfaction, and turnover intentions. Procedural Justice is associated with fairness in judgments while making a decision (Bakhshi, Kumar, \& Rani, 2009; Radburn \& Stott, 2019), used to regulate the rewards or punishment, and appraises its justice (Kim \& Beehr, 2020).

Colquitt et al. (2015) asserted that people's reactions to injustice and justice are not similar. A remarkable challenge in the literature of justice is the idea that as compared to the perception of justice rule obedience, the violation of justice rules is a robust driver of reaction. Researchers also have recognized that employee's perception of injustice increases absence due to sickness (Collins, Cartwright \& Cowlishaw, 2018); affects employees' psychiatric disorder and health (Kivimaki, et al., 2007) and many other work-related behaviors.

Erdogan, Liden, and Kraimer (2006) suggested that the amount of fairness in organizations in interpersonal treatment and rewards systems depends on what their cultural values reflect in terms of team orientation and aggressiveness. In Pakistan, the cultural aspects reflect high stress in the work environment (Abbas \& Raja, 2014), high aggressiveness, low respect for people, and low team orientation. In aggressive cultures, leaders may benefit from focusing on their interactions and making employees sure that they are treated fairly in the distribution of rewards (Erdogan et al., 2006). Little research has been previously done on the potential impact of PAJ on WE. It is a reasonable argument that employees feel good about their work in justly exchange relationship. Therefore, the study investigated the relationship between organizational justice in the performance appraisal system and WE in an exploratory manner and anticipated that performance appraisal justice would 
surge engagement. Hum resource literature is enriched with engagement and it is considered as the main element of human resource. Engagement affects the service quality of workers in any organization. Nair and Salleh (2015) endorsed that there should be an increased focus on work engagement as it may be advantageous for employees as well as for organizations to achieve distinctiveness in this world of competition.

Organizational justice has been widely recognized in the literature for predicting a variety of personal and organizational outcomes such as OCB, job performance, organizational commitment, organizational withdrawal, job satisfaction, and counterproductive behaviors at work (Kim \& Beehr, 2020; Kabat-Farr, Cortina, \& Marchiondo, 2018). Saks (2006) and Moliner et al., (2008) empirically proved that organizational justice is one of the numerous antecedents of WE. Organizational leaders can sustain justice at the workplace and are in a position to promote norms of constructive efforts (e.g. WE) among employees by serving as a role model to them (Brown \& Trevino, 2006). Organizational justice has prominent importance for understanding employee perceptions towards PAS (Palaiogos et al.,2011). Organizations should ensure justice perception in the allocation of rewards, benefits; assigning tasks, duties, and interactions between managers and employees (Sherf, Venkataramani \& Gajendran, 2019). Findings of the study conducted by Abbasi and Alvi (2012) recommend that justice in organizations plays a noteworthy role in stimulating engagement among workforces in the corporate sector, mainly the banking sector. Improved perception of organizational justice increases work engagement (̈zer et al. 2017).

$\boldsymbol{H}_{1}:$ Justice in the performance appraisal system is significantly and positively related to work engagement.

\section{Organizational Citizenship Behavior and Work Engagement}

Due to its unrestricted and advantageous nature, OCB has been renowned as a "currency" that employees can easily give or withhold (Lambert, 2000). The construct of OCB was originally coined by Barnard (1938) as "willingness to cooperate. Later Katz (1964) eluded the concept and identified some important behaviors of employees that are differential individual performance, broadening beyond formal on job requirements. According to Organ (1988), OCB refers to "individual behavior that is discretionary, not directly or explicitly recognized by the formal reward system, and in the aggregate promotes the efficient and effective functioning of the organization". Behavior that benefits the organization, in general, is OCBO Multifaceted modern-day organizations pose a challenge to developing countries to organize human resources and are reliant on the research-based guidance of managers (Kasekende, Nasiima \& Otengei, 2020). It is believed that dedication and absorption and vigor lead employees to more conscientious, altruistic, and virtuous behaviors. Based on the judgment associated with burnout, organizational citizenship behavior also can have related to WE through organizational commitment (Meynhardt, Brieger \& Hermann, 2020).

Also, explored by Demerouti, et al., (2001), WE and organizational commitment are positively correlated and it serves as a mediator between job resources and organizational commitment. Organizational commitment enhances organizational citizenship behaviors. On this basis, the study proposes that WE will be positively associated with OCB (Ehigie \& Otukoya, 2005). The notion of a 'war for talent' gives way to a quest for employees' discretionary effort (Suseno \& Pinnington, 2017).

In this competitive and hyper tempestuous work environment, a disengaged workforce is exorbitant for any organization (Huang et al., 2017). Babcock-Roberson and Strickland (2010) also found that positive higher WE positively affect OCB. Moreover, organizational commitment positively affects both WE and OCB. So, given this relationship found in the literature, the researcher argues that WE will be significantly and positively related to citizenship behavior and will surge OCB among employees.

$\boldsymbol{H}_{2}$ : Work engagement is significantly and positively related to $O C B$.

$\boldsymbol{H}_{3}$ : Work engagement mediates the relationship between organizational justice and $O C B$.

\section{Job Performance and Work Engagement}

Although task performance has the strongest effect on organizational effectiveness. It is primarily related to organizational performance and organizational goal accomplishment (Miao, Humphrey \& Qian, 2018).

While extra-role and discretionary behaviors of employees contribute to organizational performance beyond immediate task performance (Smith, Barnhill \& Sung, 2020). Job performance is one of the paramount obligations of employees with the ultimate direct effect on organizational effectiveness (Naseer et al., 2016). Lowered employee performance may be the result of a perception of injustice in performance appraisal systems of organizations. By contrast, improved job performance may be the result of perceived justice in the performance appraisal system of an organization. By including many direct and indirect variables, Gkorezis et al. (2016) confirmed that work engagement is positively related to job performance. Chong et al., (2021) pointed out that "managers should be mindful when evaluating the performance of their employees and be careful to avoid mistaking work engagement (such as spending long hours at work) for job performance or productivity". 
Previous studies in this area show continuous evidence that committed and engaged employees can lead to numerous beneficial outcomes for an organization e.g. lower turnover intents (Allen, Shore, \& Griffeth, 2003); job satisfaction (Anaza \& Rutehrford, 2012); job performance (Wang, Sui, Luthans, Wang, \&Wu, 2014; Bal \& De Lange, 2015) and greater organizational performance (Barrick et al.,2015). The need to attract and retain high-caliber employees is leading many employers to focus on work engagement as a driver of profit through turnover reduction and higher productivity through effective human capital management. Businesses with a greater level of engagement among employees enjoy a higher level of productivity ( Schaufeli, 2018).

To build on previous work, researchers believe that engaged employees are less expected to experience burnout and reduced personal success. In addition to this, because earlier researchers have found that justice is positively linked with WE (Moliner et al., 2008) and WE leads to Organizational Citizenship Behavior (Ehigie \& Otukoya, 2005; Hakanen et al., 2008; Gupta, Shaheen \& Reddy, 2017) and job performance (Wang et al., 2014; Kane-Frieder, Hochwarter, \& Ferris, 2014). More specifically, the researcher believed that justice in the performance appraisal system will be positively associated with WE, which can lead to participation in positive (in-role and extra-role) behaviors. Based on SET, researchers believe that perception of justice in the performance appraisal system reciprocates to improved WE behavior and ultimately leads to $\mathrm{OCB}$ and job performance. Researchers argue that the perception of employees about fair PAS magnifies in-role and extrarole behaviors (job performance and $\mathrm{OCB}$ ) in the presence of WE.

$\boldsymbol{H}_{4}:$ Work engagement is significantly and positively related to job performance.

$\boldsymbol{H}_{5}$ : Work engagement mediates the relationship between organizational justice and job performance.

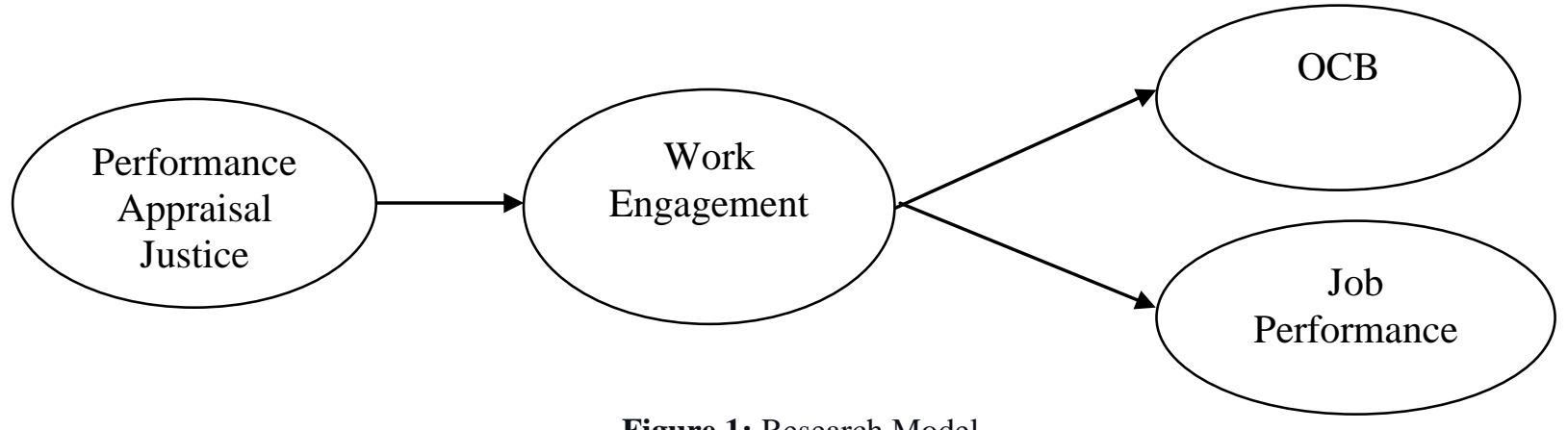

Figure 1: Research Model

Source: Developed by Authors

\section{METHOD}

\section{Sample and Data Collection Procedures}

The study is quantitative with a cross-sectional research survey design. The study sample represents white-collar workers from the Pakistani service sector which is the largest driver for economic growth (The World Bank, 2017) with a 60\% contribution in GDP. Three different service sectors banking, telecommunication, and pharmaceutical were chosen to observe the maximum variance in performance and OCB regarding justice and engagement. The inclusion criteria for the sample were employees with a minimum tenure of one year in current organization with minimum qualification intermediate and exclusion criteria was that middle and top management as they evaluate the performance of an employee and part-time employees have not been included in the sample as they differently perceive policies and jobs. So, the sample best represents the large population of white-collar workers OCB and JOB performance behaviors in the Pakistan service sector. All the chosen organizations follow merit-based recruitment systems. A total of 500 questionnaires were distributed yielded 370 returns with a 74 percent response rate. Total 325 complete useable responses (65\% effective response rate) were used in analysis after removing incomplete questionnaires. Moreover, a high sample help to generalize the results of the study.

\section{Instrument Scale Items}

A questionnaire as an instrument was used to collect the data from respondents. English is the medium of teaching in all schools, colleges, and universities in Pakistan, and employees with minimum qualifications of intermediate have good knowledge of the English language. Therefore, the study questionnaire was written in English and was personally administered to the respondents. Past workplace researches in Pakistan confirms our choice regarding the language used in the questionnaire (e.g. Naseer et al., 2016).

Work Engagement (WE): The construct of work engagement was measured by nine items scale. The scale was based on a five-point Likert scale ranging from 1 "strongly disagree" to 5 "strongly agree "of UWES-9 including three dimensions 
(vigor, dedication, absorption). Originally, the UWES consists of 24 items developed by (Schauflie et al., 2002). After psychometric evaluation, 7 items were found unused and were eliminated, Further, to make the scale more pragmatic, it has been shortened to 9 items ( Schauflie \& Bakker, 2010).

Organizational Justice: Organizational justice was evaluated built on the measure established by Colquitt (2001). The Cronbach's alphas were 0.94 for procedural justice, 0.93 for distributive justice, and interactional justice 0.91. OJ was measured employing a seven-point Likert scale ranging from 1 "strongly disagree" to 7 "strongly agree".

OCB and Job performance: The researcher has used the 21-item scale developed by Williams and Anderson (1991) to OCB. OCBI scale has a reliability score of .89 , OCBO reliability measure was .87 while the job performance had reliabilities of .96 .

\section{RESULTS}

The data were analyzed using SPSS software. The demographic profile of respondents in Table 1 shows that respondents have high school education to doctoral degrees related to their qualifications. $72 \%$ of respondents have a formal university education. Of the total respondents, $89 \%$ were male. Participants distribution across three organizations was $46 \%$ banking, $25 \%$ telecommunication, and 29\% pharmaceutical. The mean age of the sample was $34.2(S D=8.76)$ years. Demographic data show that majority of the respondents have worked with more than one organization. While the average experience was $4.35(S D=1.66)$ years with an average tenure of 4.6 years in present jobs and organizations. Data were screened for normality with the help of skewness and kurtosis. All responses were between \pm 1.5 , thereby providing evidence of normality. Furthermore, to measure inter-correlation among the variables, the study used Kaiser-Meyer-Olkin (KMO) test. Results of the measure provide evidence of a good fit of constructs of study. Respondents were guaranteed the confidentiality of their responses. Demographics detail of all samples is reported in Table.1.

Table 1: Background Information of Respondents

\begin{tabular}{llll}
\hline $\begin{array}{l}\text { Respondents' } \\
\text { group }\end{array}$ & \% of Respondents & Respondents' group & \%of Respondents \\
\hline Age & & Experience & \\
30 & 25.14 & $<3$ or 3 & 27.5 \\
$31-39$ & 32.72 & $4-15$ & 14.6 \\
$40-49$ & 19.82 & $16-27$ & 32.0 \\
$50-59$ & 10.25 & 28 or more & 25.9 \\
60 and above & 12.05 & & \\
\hline Gender & & Tenure & \\
Male & 89.0 & 1 & 15.6 \\
Female & 11.0 & $2-5$ & 36.5 \\
& & $6-9$ & 21.9 \\
& & $10-14$ & 15.0 \\
& & 15 or above & 11.0 \\
\hline Education & 28.0 & & \\
High School & & & \\
University & 72.0 & & \\
\hline
\end{tabular}

Source: Study Survey Data, 2021

Table. 2 shows mean, SDs, internal reliabilities, and inter-correlations among study variables. All measures revealed high internal reliabilities $(0.70$ to 0.93$)$. WE as a mediating variable having the highest mean value (5.28), followed by PAJ (4.76) with the lowest SD (0.57). 3.54 mean value and 1.65 SD for job performance were also in the expected direction. The correlation was consistent with the hypothesis relationship. Moreover, correlation coefficients were significant at 0.01 level and range from 0.09 to 0.81 . Results show a statistically significant positive relationship between WE and job performance $(0.28, \mathrm{p} \leq 0.01)$ and between WE and OCB $(0.37, \mathrm{p} \leq 0.01)$ respectively. Moreover, the correlation coefficient between PAJ and OCB was also according to the expectations of the researchers $(0.25, \mathrm{p} \leq 0.01)$.

Table 2: Mean, Standard Deviation and the Correlation

\begin{tabular}{|c|c|c|c|c|c|c|c|c|c|}
\hline Variables & $\mathbf{M}$ & SD & 1 & 2 & 3 & 4 & 5 & 6 & 7 \\
\hline 1. PA justice & 4.76 & 0.57 & $(0.83)$ & & & & & & \\
\hline 2.Work Engagement & 5.28 & 0.79 & $0.53 * *$ & $(0.94)$ & & & & & \\
\hline 3. Job performance & 4.54 & 0.86 & $0.34 * *$ & $0.27 * *$ & $(0.78)$ & & & & \\
\hline 4. OCB & 3.27 & 1.65 & $0.25 * *$ & $0.82 * *$ & $0.16^{* *}$ & $(0.19)$ & & & \\
\hline
\end{tabular}




\begin{tabular}{llllllllll}
\hline 5. Age & 34.2 & 8.76 & $0.37^{* *}$ & $0.85^{* *}$ & $0.14^{* *}$ & $0.45^{* *}$ & $(0.73)$ & & \\
\hline 6. Gender & 1.23 & 0.50 & $0.09^{* *}$ & $0.06^{* *}$ & $0.04^{* *}$ & $0.24^{* *}$ & $0.38^{* *}$ & $(0.68)$ & \\
\hline 7. Experience & 4.35 & 1.66 & $0.28^{* *}$ & $0.09^{* *}$ & $0.15^{* *}$ & $0.35^{* *}$ & $0.65^{* *}$ & $0.27^{* *}$ & $(0.85)$ \\
\hline
\end{tabular}

$* p<.05 ; * * p<.01 .(N=325)$

Source: Study Survey Data, 2021

The standardized regression estimates $(\beta)$ are reported in Table.3. As given by Byrne (2001), significance is based on the critical ratio (CR) of the regression estimate. Thus, $\mathrm{CR} \geq 2.58$ points to a $99 \%$ significance level. While $\mathrm{CR} \geq 1.96$ but $\leq$ 2.58 , points to a $95 \%$ significance level.

\section{Hypotheses Testing}

According to the result, performance appraisal justice regressed positively and significantly on WE ( $\beta=0.645, C R=7.85, p \leq$ $0.01)$. PAJ appeared as a powerful predictor of WE. WE regressed positively and significantly on job performance ( $\beta=0.276, C R=5.08, p \leq 0.01)$. Results are consistent with $\mathrm{H} 1$ and H2. Furthermore, WE $(\beta=0.592, C R=5.96, p \leq 0.01)$ was positively and significantly related to OCB. H3 is also accepted. Regression results are mentioned to clarify the marginal relationship among the constructs.

To assess the degree of relationship between constructs and mediating relationships, this study used analysis of moment structures (AMOS). As reported by Cohen, Cohen, West, \& Aiken (2003), mediator contributes in the influence of independent variable on the dependent variable. Model 1 includes WE as a mediator. Whereas, Model 2 tests the direct relationship between the independent and the dependent variables. In this study, the $\mathrm{c} 2=2.05$ represents a well-fitting model as it is agreeing with Byrne's (2001) values of $1.00 \leq$ normed $\mathrm{c} 2 \leq 3.00$ while GFI $=0.96$ (goodness-of-fit index) meet the criteria (GFI) $\geq 0.90$. CFI (comparative fit index) results in 0.978 are also to the finest estimates of the population value, as CFI $\geq 0.90$ indicates a good fit (Medsker, Williams, \& Holahan, 1994). According to Browne and Cudeck (1989), the favorable value of RMSEA (the root mean square error of approximation) is $\leq 0.08$ and the fair values are $\leq 0.10$. For the current study, the value of RMSEA is 0.07 . Table 4 shows that $\mathrm{H} 4$ is accepted as competing model values reflect poor fit.

Table 3: Regression estimates

\begin{tabular}{llllll}
\hline \multicolumn{6}{c}{ Unstandardized coefficient Standardized coefficient } \\
\hline \multicolumn{8}{c}{$\boldsymbol{\beta}$ Standard error } & $\boldsymbol{\beta}$ & $\boldsymbol{C R}$ & Probability & Remarks \\
\hline PAJ WE $\rightarrow 1.326$ & 0.164 & 0.645 & 7.85 & 0.000 & Hypothesis 1 accepted \\
\hline WE JP $\rightarrow 0.235$ & 0.279 & 0.276 & 5.08 & 0.000 & Hypothesis 4 accepted \\
\hline WE OCB $\rightarrow 0.200$ & 0.122 & 0.592 & 5.96 & 0.000 & Hypothesis 2 accepted \\
\hline
\end{tabular}

Source: Study Survey Data, 2021

Table 4: Indices of Model Fitness

\begin{tabular}{lllll}
\hline Fit indices & GFI & CFI & $\chi^{2}$ & RMESA \\
\hline Model 1(including mediator) & 0.964 & 0.978 & 2.05 & 0.07 \\
\hline Model 2 (without mediator) & 0.872 & 0.673 & 12.34 & 0.26 \\
\hline
\end{tabular}

Source: Study Survey Data, 2021

\section{DISCUSSION}

Hypotheses results are noteworthy to the literature. The main contribution of the study is to performance appraisal justice, WE, job performance, and OCB literature, by inspecting and confirming WE as a mechanism of mediation through which performance appraisal justice affects job performance and OCB. Employees experiencing justice in the performance appraisal system can show OCB and job performance. Results support performance appraisal justice and WE linkage and verify that performance appraisal justice to be a strong predictor of WE. These results validate that employees who found justice in PAS are more engaged and they are more likely to show OCB and high job performance at the workplace. Moreover, the results are in line with the results of empirical studies on WE, which depicts that high levels of engagement lead to improved job satisfaction, organizational commitment, motivation, performance, wellbeing, health, positive initiatives, and extra-role behaviors, while it also decreases employee turnover and absenteeism, (Salanova, Schaufeli, Xanthopoulou, \& Bakker, 2010) and "the message for organizations is clear: increasing work engagement pays off" (Wardani \& Anwar, 2019).

Organizations are battling to discover answers for creating and keeping up OCB among employees. Since OCB relies on the activity and will of representatives, their work experience gets significant (Sharma, 2019). Organizations that are fair in their 
policies, procedures, and distribution, receive a better response in terms of positive behaviors (work engagement, organizational citizenship behavior, job performance) from their employees in an exchange relationship. The study suggested that contemporary organizations should embrace justice in all their ramifications of dealings of employees. As Rubin \& Edwards (2020) also supported this notion that "Training managers and employees in the requirements of the appraisal process, and educating both on the norms and expectations underlying the system, can help to reduce conflict and ensure standards are applied consistently".

\section{CONCLUSION}

Drawing from previous research, the objective of this inquiry was to unravel how the effect of performance appraisal justice on OCB and job performance is more complex than indicated in the literature. The results of the study disclosed the supportive evidence about the direct expected relationship of understudy variables, the mediating effect of WE is likely to result in higher PAJ when bundled with organizational citizenship behavior and job performance. This is particularly found in countries that are characterized by injustice, non-transparent procedures, stressful environment, high power distance, favoritism, and growing political influence like Pakistan. The results of the existing study will encourage multiple types of organizations to implement justice in their performance appraisal systems. In such a way their performance may add benefit through the interaction of WE with OCB and job performance. As the study was conducted with limited data from Pakistani private services sector organizations, consequently the results can be generalized to public sector organizations in Pakistan.

\section{PRACTICAL IMPLICATIONS}

This research is important for managers especially in public sector organizations of Pakistan (banking, telecommunication, pharmaceutical). Keeping in WE, OCB, and job performance, managers should attempt to be just and fair during the performance evaluation of their subordinates. The managers should acknowledge and praise their hard-working employees and should encourage them for positive behaviors. Organizations should take a step to promote a just and fair environment especially in PAS and should promote employees to raise their voice against unfairness and injustice by valuing their suggestions through unanimous suggestion boxes and complaint handlings. Based on trust and belief, employers must develop a strong pledge with their employees. Moreover, all the variables of performance appraisal justice, WE, job performance, and OCB are examined in this single study.

\section{FUTURE RESEARCH DIRECTIONS}

The main objective of the study is to deepen our understanding of justice and WE literature and their relationships. This study significantly contributes to organizational justice, WE, OCB, and job performance literature despite few limitations. In Pakistan, the working of public sector organizations is mostly characterized by injustice, non-transparent procedures, stressful environment, high power distance, favoritism, and growing political influence. These factors mostly produce negative and pessimistic emotions in employees resultantly increasing deviant and counterproductive behaviors in the workplace. This research has found justice in the performance appraisal system leads to WE and ultimately leads to OCB and high job performance in government sector organizations of Pakistan. Future researchers may also conduct continuation studies on other industries and sectors. Furthermore, future studies may examine more variables as mediators and moderators amongst justice, WE, and OCB relationship.

\section{AUTHORS' CONTRIBUTIONS}

Riffut Jabeen: Writing Introduction, theory building, data collection, and data analysis.

Rabia Mushtaq: Developed conceptual framework, and literature review.

Abida Ellahi: Abstract and literature writing, proofreading, and correspondence with the journal.

Samina Begum: Worked on literature and after completing research, its review.

\section{REFERENCES}

1. Abbas, M., \& Raja, U. (2014). Impact of perceived organizational politics on supervisory-rated innovative performance and job stress: Evidence from Pakistan. Journal of Advanced Management Science, 2(2), 158-162. https://doi.org/10.12720/joams.2.2.158-162

2. Abbas, M., Raja, U., Darr, W., \& Bouckenooghe, D. (2014). Combined effects of perceived politics and psychological capital on job satisfaction, turnover intentions, and performance. Journal of Management, 40(7), 1813-1830. https://doi.org/10.1177/0149206312455243

3. Abbasi, A., \& Alvi, A. (2012). Impact of organizational justice on employee engagement in the banking sector of Pakistan. Middle-East Journal of Scientific Research 12 (5): 643-649, absence over time: A UK employee perspective. Work \& Stress, 32(1), 68-83. 
4. Adair, W. L., \& Xiong, T. X. (2018). How Chinese and Caucasian Canadians conceptualize creativity: the mediating role of uncertainty avoidance. Journal of Cross-Cultural Psychology, 49(2), 223-238. https://doi.org $\underline{/ 10.1177 / 0022022117713153}$

5. Allen, D. G., Shore, L. M., \& Griffeth, R. W. (2003). The role of perceived organizational support and supportive human resource practices in the turnover process. Journal of Management, 29(1), 99-118. https://doi.org $/ 10.1177 / 014920630302900107$

6. Anaza, N. A., \& Rutherford, B. (2012). How organizational and employee-customer identification, and customer orientation affect job engagement. Journal of Service Management, 23(5),616-639. https://doi.org/10.1108/09564231211269801

7. Babcock-Roberson, M. E., \& Strickland, O. J. (2010). The relationship between charismatic leadership, work engagement, and organizational citizenship behaviors. The Journal of Psychology, 144(3), 313-326. https://doi.org/10.1080/00223981003648336

8. Baird, K., Tung, A., \& Su, S. (2020). Employee empowerment, performance appraisal quality, and performance. Journal of Management Control, 24(1),451-474. https://doi.org/10.1007/s00187-020-00307-y

9. Bakhshi, A., Kumar, K., \& Rani, E. (2009). Organizational justice perceptions as a predictor of job satisfaction and organizational commitment. International Journal of Business and Management, 4(9), 145-154. https://doi.org/ $\underline{10.5539 / \mathrm{ijbm} . v 4 \mathrm{n} 9 \mathrm{p} 145}$

10. Bal, P. M., \& De Lange, A. H. (2015). From flexibility human resource management to employee engagement and perceived job performance across the lifespan: A multisample study. Journal of Occupational and Organizational Psychology, 88(1), 126-154. https://doi.org/10.1111/joop.12082

11. Barnard, C. I. (1938). The functions of the executive.Cambridge, MA: Harvard University Press

12. Barrick, M. R., Thurgood, G. R., Smith, T. A., \& Courtright, S. H. (2015). Collective organizational engagement: Linking motivational antecedents, strategic implementation, and firm performance. Academy of Management Journal, 58(1), 111-135. https://doi.org/10.5465/amj.2013.0227

13. Blau, P. M. (1964). Justice in social exchange. Sociological Inquiry, 34(2), 193-206. https://doi.org/10.1111/j.1475682X.1964.tb00583.X

14. Brown, M.E. and Trevino, L.K. (2006). Ethical leadership: a review and future directions, The Leadership Quarterly, 17( 6), 595-616. https://doi.org/10.1016/j.leaqua.2006.10.004

15. Browne, M. W., \& Cudeck, R. (1989). Single sample cross-validation indices for covariance structures. Multivariate Behavioral Research, 24(4), 445-455. https://doi.org/10.1207/s15327906mbr2404_4

16. Byrne, B. M. (2001). Structural equation modeling with AMOS, EQS, and LISREL: Comparative approaches to testing for the factorial validity of a measuring instrument. International Journal of Testing, 1(1), 55-86. https://doi.org/10.1207/S15327574IJT0101_4

17. Chen, Y. J., Li, P., \& Lu, Y. (2018). Career concerns and multitasking local bureaucrats: Evidence of a target-based performance evaluation system in China. Journal of Development Economics, 133(1), 84-101. https://doi.org/ 10.1016/j.jdeveco.2018.02.001

18. Chong, S., Van Dyne, L., Kim, Y. J., \& Oh, J. K. (2021). Drive and direction: empathy with intended targets moderates the proactive personality-job performance relationship via work engagement. Applied Psychology, 70(2), 575-605. https://doi.org/10.1111/apps.12240

19. Cohen, J., Cohen, P., West, S. G., \& Aiken, L. S. (2013). Applied multiple regression/correlation analysis for the behavioral sciences. Routledge. https://doi.org/10.4324/9780203774441

20. Collins, A. M., Cartwright, S., \& Cowlishaw, S. (2018). Sickness presenteeism and sickness critical review with theoretical remedies. Academy of Management Annals, 11(1), 479-516.

21. Colquitt, J. A. (2001). On the dimensionality of organizational justice: construct validation of a measure. Journal of Applied Psychology, 86(3), 386. https://doi.org/10.1037/0021-9010.86.3.386

22. Colquitt, J. A., Greenberg, J., \& Zapata-Phelan, C. P. (2005). What is organizational justice? A historical overview. Handbook of Organizational Justice, 1, 3-58.

23. Colquitt, J. A., Long, D. M., Rodell, J. B., \& Halvorsen-Ganepola, M. D. (2015). Adding the "in" to justice: A qualitative and quantitative investigation of the differential effects of justice rule adherence and violation. Journal of Applied Psychology, 100(2), 278. https://doi.org/10.1037/a0038131

24. Cropanzano, R., Anthony, E. L., Daniels, S. R., \& Hall, A. V. (2017). Social exchange theory: A

25. Demerouti, E., Bakker, A. B., Nachreiner, F., \& Schaufeli, W. B. (2001). The job demands-resources model of burnout. Journal of Applied Psychology, 86(3), 499. https://doi.org/10.1037/0021-9010.86.3.499

26. Ehigie, B. O., \& Otukoya, O. W. (2005). Antecedents of organizational citizenship behaviors in a governmentowned enterprise in Nigeria. European Journal of Work and Organizational Psychology, 14(4), 389-399. https://doi.org/10.1080/13594320544000019 
27. Erdogan, B., Liden, R. C., \& Kraimer, M. L. (2006). Justice and leader-member exchange: The moderating role of organizational culture. Academy of Management Journal,49(2), 395-406. https://doi.org/10.5465/amj .2006 .20786086

28. Fatt, C. K., Khin, E. W. S. \& Heng, T. N. (2010). The impact of organizational justice on employee Job satisfaction: The Malaysian company's perspective, American Journal of Economics and Business Administration.2(1),56-63. https://doi.org/10.3844/ajebasp.2010.56.63

29. Flint, D. H., \& Haley, L. M. (2013). Distributive justice in human resource management: A multisystem approach. The Journal of American Business Review, Cambridge, 2(1), 50-57.

30. Gkorezis, P., Bellou, V., Xanthopoulou, D., Bakker, A. B., \& Tsiftsis, A. (2016). Linking football team performance to fans' work engagement and job performance: Test of a spillover model. Journal of Occupational and Organizational Psychology, 89(4), 791-812. https://doi.org/10.1111/joop.12155

31. Gul, H., Usman, M., Liu, Y., Rehman, Z., \& Jebran, K. (2018). Does the effect of power distance moderate the relation between person-environment fit and job satisfaction leading to job performance? Evidence from Afghanistan and Pakistan. Future Business Journal, 4(1), 68-83. https://doi.org/10.1016/j.fbj.2017.12.001

32. Gupta, M., Shaheen, M., \& Reddy, P. K. (2017). Impact of psychological capital on organizational citizenship behavior: Mediation by work engagement. Journal of Management Development. 36 (7), 973-983. https://doi.org/10.1108/JMD-06-2016-0084

33. Hakanen, J. J., Perhoniemi, R., \& Toppinen-Tanner, S. (2008). Positive gain spirals at work: From job resources to work engagement, personal initiative, and work-unit innovativeness. Journal of Vocational Behavior, 73(1), 78-91. https://doi.org/10.1016/j.jvb.2008.01.003

34. Huang, G. H., Wellman, N., Ashford, S. J., Lee, C., \& Wang, L. (2017). Deviance and exit: The organizational costs of job insecurity and moral disengagement. Journal of Applied Psychology, 102(1), 26. https://doi.org/10.103 7/ap10000158

35. Imamoglu, S. Z., Ince, H., Turkcan, H., \& Atakay, B. (2019). The effect of organizational justice and organizational commitment on knowledge sharing and firm performance. Procedia Computer Science, 158, 899-906. https://doi.org/10.1016/j.procs.2019.09.129

36. Kabat-Farr, D., Cortina, L. M., \& Marchiondo, L. A. (2018). The emotional aftermath of incivility: Anger, guilt, and the role of organizational commitment. International Journal of Stress Management, 25(2), 109-128. https://doi.org/10.1037/str0000045

37. Kane-Frieder, R. E., Hochwarter, W. A., \& Ferris, G. R. (2014). Terms of engagement: Political boundaries of work engagement-work outcomes relationships. Human Relations, 67(3), 357-382. https://doi.org/10.1177/001872671 $\underline{3495068}$

38. Kasekende, F., Nasiima, S., \& Otengei, S. O. (2020). Strategic human resource practices, emotional exhaustion, and OCB: the mediator role of person-organization fit. Journal of Organizational Effectiveness: People and Performance. 7(3), 275-295. https://doi.org/10.1108/JOEPP-04-2020-0056

39. Katz, D. (1964). The motivational basis of organizational behavior, Behavioral Science, 9(2),131-146. https://doi.org/10.1002/bs.3830090206

40. Kausar, R., \& Anwar, T. (2010). Perceived stress, stress appraisal, and coping strategies used in relation to television coverage of terrorist incidents. Pakistan Journal of Social and Clinical Psychology, 8(2), 119-131.

41. Khan, M. A., Hussain, A., Hussain, J., \& Khan, M. H. (2020). Effect of Performance Appraisal on Employees' Satisfaction: A Case Study of the University of Peshawar, Khyber Pakhtunkhwa, Pakistan. Review of Applied Management \& Social Science, 3(2), 131-140. https://doi.org/10.47067/ramss.v3i2.40

42. Khan, N., Jackson, D., Stayt, L., \& Walthall, H. (2019). Factors influencing nurses' intentions to leave adult critical care settings. Nursing in Critical Care, 24(1), 24-32. https://doi.org/10.1111/nicc.12348

43. Kim, M., \& Beehr, T. A. (2020). Empowering leadership: leading people to be present through affective organizational commitment?. The International Journal of Human Resource Management, 31(16), 2017-2044. https://doi.org/10.1080/09585192.2018.1424017

44. Kim, M., \& Beehr, T. A. (2020). Empowering leadership: leading people to be present through affective organizational commitment?. The International Journal of Human Resource Management, 31(16), 2017-2044. https://doi.org/10.1080/09585192.2018.1424017

45. Kivimäki, M., Vahtera, J., Elovainio, M., Virtanen, M., \& Siegrist, J. (2007). Effort-reward imbalance, procedural injustice, and relational injustice as psychosocial predictors of health: complementary or redundant models? Occupational and Environmental Medicine, 64(10), 659-665. https://doi.org/10.1136/oem.2006.031310

46. Lambert, S. (2000). Added benefits: The link between work-life benefits and organizational citizenship behavior, Academy of Management Journal, 43(5), 801-815. https://doi.org/10.2307/1556411 
47. Medsker, G. J., Williams, L. J., \& Holahan, P. J. (1994). A review of current practices for evaluating causal models in organizational behavior and human resources management research. Journal of Management, 20(2), 439-464. https://doi.org/10.1177/014920639402000207

48. Meynhardt, T., Brieger, S. A., \& Hermann, C. (2020). Organizational public value and employee life satisfaction: The mediating roles of work engagement and organizational citizenship behavior. The International Journal of Human Resource Management, 31(12), 1560-1593. https://doi.org/10.1080/09585192.2017.1416653

49. Miao, C., Humphrey, R. H., \& Qian, S. (2018). A cross-cultural meta-analysis of how leader emotional intelligence influences subordinate task performance and organizational citizenship behavior. Journal of World Business, 53(4), 463-474. https://doi.org/10.1016/j.jwb.2018.01.003

50. Moliner, C., Martı 'Nez-Tur, V., Ramos, J., Peiro', J.M. \& Cropanzano, R. (2008). Organizational justice and extrarole customer service: the mediating role of wellbeing at work, European Journal of Work and Organizational Psychology, 17(3), 327-48. https://doi.org/10.1080/13594320701743616

51. Murphy, K. R. (2020). Performance evaluation will not die, but it should. Human Resource Management Journal, 30(1), 13-31. https://doi.org/10.1111/1748-8583.12259

52. Nair, M.S., \& Salleh, R. (2015). Linking performance appraisal justice, trust, and employee engagement: A conceptual framework. Procedia-Social and Behavioral Sciences, 211, 1155-1162. https://doi.org/10.1016/j.sb spro.2015.11.154

53. Naseer, S., Raja, U., Syed, F., Donia, M. B., \& Darr, W. (2016). Perils of being close to a bad leader in a bad environment: Exploring the combined effects of despotic leadership, leader-member exchange, and perceived organizational politics on behaviors. The Leadership Quarterly, 27(1), 14-33. https://doi.org/10.1016/j.lea qua.2015.09.005

54. Organ, D. W. (1988). Organizational citizenship: The good soldier syndrome. Lexington, MA: Lexington Books.

55. Özer, Özlem, Özgür Uğurluoğlu, \& Meltem Saygi. (2017). Effect of organizational justice on work engagement in the healthcare sector of Turkey. Journal of Health Management 19: 73-83. https://doi.org/10.1177/0972 063416682562

56. Palaiogos, A., Papazekos, P. \& Panayotopoulou, L. (2011). Organizational Justice \& Employee Satisfaction in Performance Appraisal. Journal of European Industrial Training, 35(8):826-840. https://doi.org/10.1108/03 090591111168348

57. Podsakoff, N. P., Whiting, S. W., Podsakoff, P. M., \& Blume, B. D. (2009). Individual-and organizational-level consequences of organizational citizenship behaviors: A meta-analysis. Journal of Applied Psychology, 94(1), 122. https://doi.org/10.1037/a0013079

58. Radburn, M., \& Stott, C. (2019). The social-psychological processes of 'procedural justice': Concepts, critiques, and opportunities. Criminology \& Criminal Justice, 19(4), 421-438. https://doi.org/10.1177/1748895818780200

59. Rubin, E. V., \& Edwards, A. (2020). The performance of performance appraisal systems: understanding the linkage between appraisal structure and appraisal discrimination complaints. The International Journal of Human Resource Management, 31(15), 1938-1957. https://doi.org/10.1080/09585192.2018.1424015

60. Rupp, D. E., Shapiro, D. L., Folger, R., Skarlicki, D. P., \& Shao, R. (2017). A critical analysis of the conceptualization and measurement of organizational justice: Is it time for reassessment? Academy of Management Annals, 11(2), 919-959. https://doi.org/10.5465/annals.2014.0051

61. Saks, A.M. (2006). Antecedents and consequences of employee engagement, Journal of Managerial Psychology, 21(7), 600-19. https://doi.org/10.1108/02683940610690169

62. Salanova, M., Schaufeli, W. B., Xanthopoulou, D., \& Bakker, A. B. (2010). The gain spiral of resources and work engagement: Sustaining a positive work-life. Work Engagement: A handbook of essential theory and research, 118131.

63. Schaufeli, W. B. (2018). Work engagement in Europe: Relations with the national economy, governance, and culture. Organizational Dynamics, 47, 99-106. https://doi.org/10.1016/j.orgdyn.2018.01.003

64. Schaufeli, W. B., \& Bakker, A. B. (2010). Defining and measuring work engagement: Bringing clarity to the concept. Work engagement: A handbook of essential theory and research, 12, 10-24.

65. Schaufeli, W. B., Bakker, A. B., \& Salanova, M. (2006). The measurement of work engagement with a short questionnaire: A cross-national study. Educational and Psychological Measurement, 66(4), 701-716. https://doi.org/10.1177/0013164405282471

66. Schaufeli, W. B., Salanova, M., González-Romá, V., \& Bakker, A. B. (2002). The measurement of engagement and burnout: A two sample confirmatory factor analytic approach. Journal Of Happiness Studies, 3(1), 71-92. https://doi.org/10.1023/A:1015630930326

67. Schneider, B., Yost, A. B., Kropp, A., Kind, C., \& Lam, H. (2018). Workforce engagement: What it is, what drives it, and why it matters for organizational performance. Journal of Organizational Behavior, 39(4), 462-480. https://doi.org/10.1002/job.2244 
68. Shanock, L. R., Eisenberger, R., Heggestad, E. D., Malone, G., Clark, L., Dunn, A. M., Kirkland, J., \& Woznyj, H. (2019). Treating employees well: The value of organizational support theory in human resource management. The Psychologist-Manager Journal, 22(3-4), 168-191. https://doi.org/10.1037/mgr0000088

69. Sharma, A. (2019). Meaningfulness of work and perceived organizational prestige as precursors of organizational citizenship behavior. Humanities \& Social Sciences Reviews, 7(1), 316-323. https://doi.org/10.185 10/hssr.2019.7136

70. Sherf, E. N., Venkataramani, V., \& Gajendran, R. S. (2019). Too busy to be fair? The effect of workload and rewards on managers' justice rule adherence. Academy of Management Journal, 62(2), 469-502. https://doi.org/ 10.5465/amj.2016.1061

71. Shin, Y., Du, J., \& Choi, J. N. (2015). Multi-level longitudinal dynamics between procedural justice and interpersonal helping in organizational teams. Journal of Business and Psychology,30(3), 513-528. https://doi.org/10.1007/s10869-014-9379-0

72. Smith, N. L., Barnhill, C., \& Sung, H. (2020). Effects of employees' extra-role behaviors on organizational performance: An assessment of Minor League Baseball team front offices. Journal of Global Sport Management, 5(4), 349-366. https://doi.org/10.1080/24704067.2020.1731702

73. Suseno, Y., \& Pinnington, A. H. (2017). The war for talent: Human capital challenges for professional service firms. Asia Pacific Business Review, 23(2), 205-229. https://doi.org/10.1080/13602381.2017.1287830

74. The World Bank (2017). Pakistan Development Update. http://documents1.worldbank org/curated/en/53643149522 5444544

75. Thomas, L., Ambrosini, V., \& Hughes, P. (2019). The role of organizational citizenship and rewards in strategy effectiveness. The International Journal of Human Resource Management, 30(18), 2628-2660. https://doi.org/1 $0.1080 / 09585192.2017 .1391312$

76. Van Dijke, M., De Cremer, D., Langendijk, G., \& Anderson, C. (2018). Ranking low, feeling high: How hierarchical position and experienced power promote prosocial behavior in response to procedural justice. Journal of Applied Psychology, 103(2), 164-181. https://doi.org/10.1037/ap10000260

77. Wang, H., Sui, Y, Luthans, F., Wang, D., \& Wu, Y. (2014). Impact of authentic leadership on performance: Role of followers' positive psychological capital and relational processes. Journal of Organizational Behavior, 35(1), 5-21. https://doi.org/10.1002/job.1850

78. Wang, K.Y. \& Nayir, D.Z. (2010). Procedural justice, participation and power distance: information sharing in Chinese firms. Management Research Review, 33(1): 66-78. https://doi.org/10.1108/01409171011011571

79. Wardani, L. M. I., \& Anwar, M. S. (2019). The role of quality of work-life as mediator: Psychological capital and work engagement. Humanities \& Social Sciences Reviews, 7(6), 447-463. https://doi.org/10.18510/hssr.2019.7670

80. Williams, L. J., \& Anderson, S. E. (1991). Job satisfaction and organizational commitment as predictors of organizational citizenship and in-role behaviors. Journal of Management, 17(3), 601-617. https://doi.org/10.1177/ 014920639101700305

81. Zhou, J., Zhang, C., Shen, L., \& Zhou, K. Z. (2020). Interpersonal guanxi and partner extra-role behavior: Mediating role of relational and transactional governance strategy. Industrial Marketing Management, 91, 551-562. https://doi.org/10.1016/j.indmarman.2020.03.022 